Anna-Christine Weirich*

\title{
Access and reach of linguistic repertoires in periods of change: a theoretical approach to sociolinguistic inequalities
}

\author{
https://doi.org/10.1515/ijsl-2020-0047
}

Received July 7, 2020; accepted January 4, 2021; published online August 16, 2021

\begin{abstract}
The two notions of scope and access connect an understanding of societal multilingualism in a socio-economic context (linguistic relations) with the analysis of individual multilingualism (linguistic repertoires and linguistic practice). These notions produce a theoretical framework for discussing sociolinguistic inequalities that links the macro-level of social relations with the micro perspective of specific individuals and practices. Linguistic relations are dynamic and can undergo abrupt changes that urge multilingual speakers to restructure their linguistic repertoires to adapt to altered linguistic relations. With the help of the concepts of access and scope, we can describe which social functions specific linguistic resources have (scope) and how speakers are positioned to acquire these resources (access). This describes the relation of speakers to their linguistic resources as currently (un)available (scope) and potentially (un)learnable (access), depending on the social context in which they are practiced. Using these notions as a theoretical framework, this text discusses two scenarios of change connected to mobility and immobility illustrated with examples from research in the Republic of Moldova. The first case is one of ruptured sociolinguistic relations because of drastic changes in a state's language policies with which immobile speakers are confronted. A highly qualified Moldovan labor migrant in Italy serves as an example of mobility.
\end{abstract}

Keywords: inequalities; linguistic biographies; linguistic repertoires; mobility; sociolinguistics

\section{Introduction}

Ştiţi / cum să vă spun / eram / am făcut şi aşa lucruri cînd toată ziua nu vorbeai cu nimeni [...] sau de exmplu am făcut doi ani tot baby sitter cu o

\footnotetext{
*Corresponding author: Anna-Christine Weirich, Goethe-Universität, Frankfurt, Germany, E-mail: a.weirich@em.uni-frankfurt.de
} 
fetiţă de la cinci zile [...] era micuţă nu (.) cînd [era] mai mare tot îi vorbeai la dînsa clar lucru 2 ani tot una nu prea vorbeşte [...] că erau zile nu vorbeam cu nimeni [...] (.) făcei muncă plecai ai închis uşa şi te-ai dus

(You know, how shall I say, I was - I also had jobs where you did not speak to anyone the whole day. For example, for two years, I was a babysitter for a little girl, starting from the age of five days. She was so small. When she grew a little older, of course, I spoke with her. But anyway, even with a twoyear-old, you don't have that kind of conversation. And there were days when I spoke to no one. You did the work, closed the door, and then you left

(2) cînd veneai acasă seara televizorul (.) cîteodată da dar cîteoda $\mathrm{n}($.$) nu era$ (.) nimic de nevoie luai o revistă (.) mă rog de publicitate [...] de: (.) nu-i mare: (.) ştiinţă aşa numai uşurică să fie [...] eu cam în glumă spuneam ca să nu uit literele (.) [...] am avut un mod de viaţă altul (.) eu trebuia să ies în faţa studenţilor să stau de vorbă să fiu la curent cu toate noutăţile să discut cîte ceva (.) să scriu nişte lucrări metodice [...] şi cînd vii acolo nu ţii tocul în mînă (.) picsul nu scrii (.) [...] nu ai alti (.) altă viaţă totală

(When you came home in the evening, television. Sometimes, but sometimes there was nothing on. So you had no choice, but to take a journal. I mean advertising leaflets kind of, no big science. It had to be simple. In order not to forget the letters, I joked. I had a very different life (before). I had to stand in front of the students, I had to be up-to-date in order to discuss, I was writing methodic publications. And then you arrive there (in Italy), and you don't even pick up a pen anymore. It's a completely different life)

Viorela ${ }^{1}$ had invested a lifetime in shaping and enhancing her linguistic repertoire in everyday life in Chişinău and the professional context of academia, pursuing her career as a professor of physical education at the Moldovan State University. Moving to Italy for work, she had to give up the big reach of her repertoire, at least temporarily. Her linguistic repertoire did not have the same scope in Italy as it did in Chişinău. In Rome, she began learning Italian to make herself understood in everyday life and her jobs. Doing care work in Italian households, she was detached from the professional and scientific discourses of her expertise as well as the forms of cultural discourses and consumption to which she was accustomed.

The linguistic resources needed were entirely different from those necessary in her former life because linguistic relations in Italy differed from those in the Republic of Moldova. Her linguistic repertoire had less scope within these linguistic

1 Interview conducted by the author on 10 May 2012, Chişinău (call center), 80:59 min. 
relations. At the same time, as an immigrant, working as a badante, ${ }^{2}$ she was detached from the sort of communication that would have provided her with the linguistic practice she needed to elaborate on her linguistic knowledge. Access to this kind of linguistic practice was difficult or impossible in the early years in Italy.

Contrasting cases of mobility such as Viorela's with cases of immobility, this article presents a theoretical approach to describing linguistic inequalities with the help of the notions of scope and access. These two hinge notions connect descriptions of societal multilingualism in a socio-economic context (linguistic relations) with the analysis of individual multilingualism (linguistic repertoires and linguistic practice). To outline this approach, I will explain the background of my choice of the notions (socio)linguistic relations on the macro level and linguistic repertoires for the micro perspective. I argue that linguistic relations are dynamic and can undergo abrupt changes. In doing so, I discuss two rupture scenarios connected to mobility and immobility by illustrating them with two examples from research in the Republic of Moldova. The first case is one of rupture in the sociolinguistic relations because of drastic changes in the state's language policies with which immobile speakers must deal. The example chosen to illustrate this case of change in linguistic relations is the "double minoration" of speakers of Ukrainian after the Republic of Moldova's independence. Viorela is exemplary for the case of mobility. She is one of several thousand highly qualified Moldovan labor migrants working in households in Italy. She is also an example of circular migration that requires constant adaptation to different and sometimes new linguistic relations.

\section{Linguistic relations}

Field research in the Republic of Moldova (2010-2016) led to the development of a theory of linguistic relations (sprachliche Verhältnisse), linguistic repertoires,

2 The Italian term 'badante' designates care workers. In the context of labour migration to Italy it refers more specifically to geriatric nurses and nursemaids who live and work in Italian households and care for elderly people and/or children. The term has to be used with caution because it can have a disparaging connotation. See Vietti (2012) for an insightful account of Moldovan women's experiences as badante in Italy.

3 The research project "Linguistic Dynamics in a Multiethnic National State: the Republic of Moldova”, 2010-2013, (financed by the German Research Foundation, DFG, coordinated by Jürgen Erfurt) was interested in monolingual and multilingual institutions in the former Sovietic republic. It had a special focus on linguistic minorities and allophone speakers. In an ethnographic approach, the author conducted two case studies as part of this project, focusing on the intersection of labour and linguistic biographies: one in the school (liceu) of a Ukrainian-speaking village and one in an Italian-speaking call center in the Moldovan capital Chişinău (Weirich 2018, 2021a, 2021b). 
access (Erreichbarkeit), and scope (Reichweite) that provides a framework for interpreting the linguistic dimension of social inequalities (Weirich 2018). Such an approach was needed to understand better how the rupture and transformation of linguistic relations in a society affect multilingual speakers with diverse repertoires. How does the declaration of a new state language affect the position of speakers in society? How does it influence their access to education, work, and other spheres of social life? How does it affect their capacity to speak and write? How do speakers adapt to changing linguistic relations, and how do they transform their linguistic repertoires while doing so? The resulting theoretical framework is abstract enough to be applied to any sociolinguistic situation, helping to ethnographically describe sociolinguistic inequalities on the micro-level of individual trajectories (as exemplified by the example of Viorela) or on the meso-level of relatively small social groups (such as a village). It permits to consider other social factors that impact scope of and access to linguistic resources.

This framework contributes to sociolinguistic theory by providing principles for explaining specific sociolinguistic phenomena from a particular perspective: linguistic inequalities and having voice. Although its aim is not to explain traditional sociolinguistics phenomena such as variation, language choice, or linguistic change, these are intrinsically linked to scope of and access to linguistic resources. The advantage of the theoretical framework presented here is that it can easily integrate approaches concerned with other sociolinguistic phenomena that want to bridge the micro-macro divide (Heller 2016; Romaine 2000).

This framework is most appropriately applied in ethnographic research. It is a tool to deduce hypotheses rather than a theory that makes predictions. However, at a general level, it formulates rules: if an individual's linguistic repertoire has high scope in a given context, he or she has good (linguistic) conditions for having voice. If access to linguistic resources with scope is given, the speaker's conditions for acquiring the linguistic means necessary for having voice are good. In making a claim to consider social categorizations such as race, gender, class, ability, it reminds researchers to consider factors beyond linguistic forms that influence how interlocutors evaluate linguistic practice based on norms and language ideologies. Beyond that, the framework remains rather abstract: scope can consist of a wide range of practices. Public communication (in the official language) is always a central aspect because so many aspects of participation and social well-being depend on it. But the specific articulation of sociolinguistic relations in spaces and social groups to which the individual adheres differ enormously between citizens of the same state, persons living in the same city, and even between friends and family members. But I argue that whatever the linguistic forms, practices, and ideologies at stake are in a particular context, asking for scope and access will help 
understand how an individual is positioned to participate and pronounce their interests, e.g., having voice.

From the individual and ontogenetic perspective, the ethnographic repertoire approach convincingly describes how plurilingual individuals deal with a multilingual environment while occupying a specific social position:

\footnotetext{
Voice, as we know, is subject to normative judgment - one has voice when someone else ratifies it as such. In that sense, our subject's repertoire is a complex of traces of power: a collection of resources our subject had to accumulate and learn in order to make sense to others, that is, in order to operate within the norms and expectations that govern social life in the many niches in which he dwelled and through which he passed. The elements of the repertoire are resources he needed to deploy, practices he had to perform, in order to be "normal" in the polycentric and dynamic world in which he lived. (Blommaert and Backus 2011: 23)
}

While sticking to the linguistic repertoire in describing individual multilingualism, I was looking for a middle-range theory that considers macro-sociolinguistic relations and individual multilingualisms at the same time: a theory that helps to understand what sociolinguistic relations and linguistic inequality mean for individuals and how they are reproduced by social practice (Heller 2008: 517). Sociolinguistic inequalities are rooted in linguistic relations. Linguistic relations are part of social relations - they are interdependent with economic relations, gender, and race. That is why understanding sociolinguistic equality must also be about defining the place of language and of the individual's capacity to express oneself in a given context. This capacity depends on more than the individual's and society's linguistic resources and norms. I am using the term voice to describe a situation in which individuals can express themselves and are being listened to (see Section 4). In this sense, voice is one of the most important targets and motivational factors of language learning processes.

I am proposing the notion of linguistic relations (sprachliche Verhältnisse) as developed in the works of German linguists Utz Maas (2008, 2010), Klaus Bochmann $(1997,2007)$ and Jürgen Erfurt $(1994,2002,2003)$ as a theoretical framework for describing the sociolinguistic conditions with which speakers are confronted on an everyday basis. The notions of scope and access help specify how sociolinguistic inequalities are (re)produced under certain sociolinguistic relations. They help to understand how individual linguistic repertoires (Blommaert 2010; Blommaert and Backus 2013; Busch 2012, 2013, 2016; Lüdi 2014; Lüdi and Py 2009) are restructured as a reaction to linguistic relations. Linguistic relations as a notion can appear transparent in everyday, non-scientific language. It contributes to comprehensibility, but it can also imply a lack of specificity, so I give a detailed account of its meaning and theoretical background in this section. 
The discussion is based on the works of Utz Maas (2008), who uses it in the context of his "theory of linguistic elaboration" (German: "Theorie des sprachlichen Ausbaus"). He investigates individual repertoire elaboration by looking at exclusion mechanisms that are at stake when learning language(s). More specifically, having knowledge of and capacities to use formal registers of the standard language is critical for participation in modern democratic and capitalist states. From a political perspective, this allows speakers to reclaim efforts for establishing the linguistic conditions that permit social and political participation.

Maas focuses on the ontogenetic perspective of children's language elaboration processes and specifically developing literacy. This paper presents a theoretical framework that describes what linguistic resources and linguistic practice mean for the positioning of individuals in the context of social relations that can also be used to explain processes that mobile multilingual adults face. In this context, my own working definition of "sociolinguistic relations" is:

Linguistic relations exist between all languages, varieties, and registers practiced in a national state. These relations depend on the distribution of their functions, their evaluations, their role in the regulation of access to political and economic participation, and their accessibility in learning. Linguistic relations are dynamic, and they can undergo dramatic changes in times of social rupture and of redefinition of social power relations.

Maas' perspective of linguistic relations privileges the nation-state as the scale on which linguistic relations are situated, although they vary within states and reach across state borders. However, the state (or sometimes regions or provinces) is the scale on which the official language(s) (Geschäftssprachen) are declared and established as the top criterion of linguistic exclusion. Ideas about language are not neutral but related to "the many other ways in which we make sense of the world" (Heller 2008: 518). Culture-specific language ideologies underpin the reproduction and distribution of linguistic resources. Often official language policies go hand in hand with ideologies of monolingualism (Heller 2016: 213). In contrast to this, the heterogeneity of linguistic practice and the functions of different languages and varieties in a society can be taken into account with the notion of linguistic relations.

Linguistic relations exist between linguistic forms, varieties, and registers concerning their functions, use, and norms that are applied to them. Language ideologies that serve particular interests are involved in linguistic relations and vary across time and space (Duchêne and Heller 2008). They allocate value to linguistic forms and practices and contribute to the construction of social difference and inequality (Heller 2008). Maas attributes specific importance to the relation of spoken and written language, or, more specifically, the spontaneous oral language and its idiomatization in the elaboration of literacy (Maas 2008: 261). 
He distinguishes the medium - oral or written - from registers (orate and literate) with different functions. Registers are orthogonal to varieties, which Maas understands in the strict sense of functional equivalents as opposed to registers that point to different degrees of formality and complexity.

The modern nation-state necessitates subjective identification since one of its founding principles is participation (Erfurt 1994: 29; Maas 1989: 23f). Such states depend on the "demotisation" of literacy (Maas 1985: 57). In other terms: citizens must (potentially) have access to literacy (Maas 2005: 111). Socioeconomically and politically, the modern state depends on transregional (nationwide) communication with and between its citizens, especially in the written medium. Simultaneously, the unequal distribution of linguistic resources and dimensions of linguistic distinction is inherent to the working modus of the state. Possibilities of participation (and processes of exclusion) are inherent in linguistic relations (Maas 2008: 127) because the working language of the state (Geschäftssprache) and its formal registers have essential functions (scope), but access to them is unequally distributed.

\subsection{Ruptures in sociolinguistic relations}

Making yourself listened to and understood (attempting to have voice) is an “intrinsically social process" (Blommaert 2008: 427), connected to social structure, history, culture and power relations, a dialogical practice in Bakhtin's sense. Developing voice is a challenge in any society and historical situation. Understanding how linguistic relations work and learning powerful ways of speaking under these conditions can take years of learning, empowerment, and practice. However, individuals and groups who used to have voice under specific linguistic relations stand to lose it if these relations change. In a biographic perspective, moments that change the usual course of everyday life are referred to as "breaks" or “fissures" (German: Brüche) (Bochmann 2007: 32). From the individual's point of view, this can happen because of biographic events (like entering school or starting a job) or migration, but also due to politico-historical cesuras. Although established sociolinguistic relations are dynamic and undergo long-term change (Bot et al. 2007), historical events can cause drastic shifts (Bochmann 2007: 32), which establish new sociolinguistic relations. A typical example of this would be the declaration of a new official language. Of course, language policy alone cannot entirely change linguistic relations as they also consist of the linguistic resources the members of society have and practices they maintain or change. However, such policies can pressure individuals to learn new linguistic resources and devaluate their linguistic repertoires. This requires individual speakers to adapt to the new 
linguistic relations and, eventually, restructure their linguistic repertoires (to have voice under the new circumstances). When individuals "lack time or vital resources" to adapt to these "sudden change(s) of the physical and, first of all social environment” (Busch 2016: 3), such disruptive events can be traumatic. Language and narrative are crucial to coping with such changes because they help to

assimilate such a lived event into one's personal perception, to relate it to previous experiences and memories (Janet 1904). The difficulty of putting traumatic experience into words, of representing it symbolically through language and integrating it into a narrative of the Self derives precisely from this impossibility of assimilation and connection to the world of one's experiences. (Busch 2016: 3)

In this sense, several individuals experiencing the same situation have different communicative resources to deal with them.

\subsection{Access and scope of linguistic repertoires}

The notions of access and scope connect the individual perspective of linguistic biographies and learning processes with sociolinguistic relations, as described above. It discusses them in the context of linguistic relations to understand how social inequality and linguistic resources are connected. They shed light on individual strategies to deal with linguistic relations that have emerged in historical processes and are the product of struggles over power and resources. Autonomy, having voice, and participation are what motivates elaboration and learning processes (Figure 1).

Through the concepts access and scope, we can describe the social functions that specific linguistic resources have (scope) and how speakers are positioned to acquire these resources (access). This pair captures the relation of speakers to their linguistic resources as currently (un)available (scope) and potentially (un)learnable (access), depending on the social context in which they are practiced. The functions and possible actions that certain linguistic resources make available to speakers under specific sociolinguistic circumstances, including the potential for voice, constitute the scope of linguistic resources. Scope entails such aspects as the practical communicative use, the possibility to "commodify" (Heller and Duchêne 2012; Holborow 2015), or the possibility to participate in a democratically legitimated state. But it also encapsulates aspects like social capital and privileges related to voice and recognition.

Access to linguistic resources depends on the opportunities a speaker has to learn certain languages, registers and linguistic forms. It is an important factor of social inclusion and exclusion. Linguistic resources with high scope (e.g., a state's 


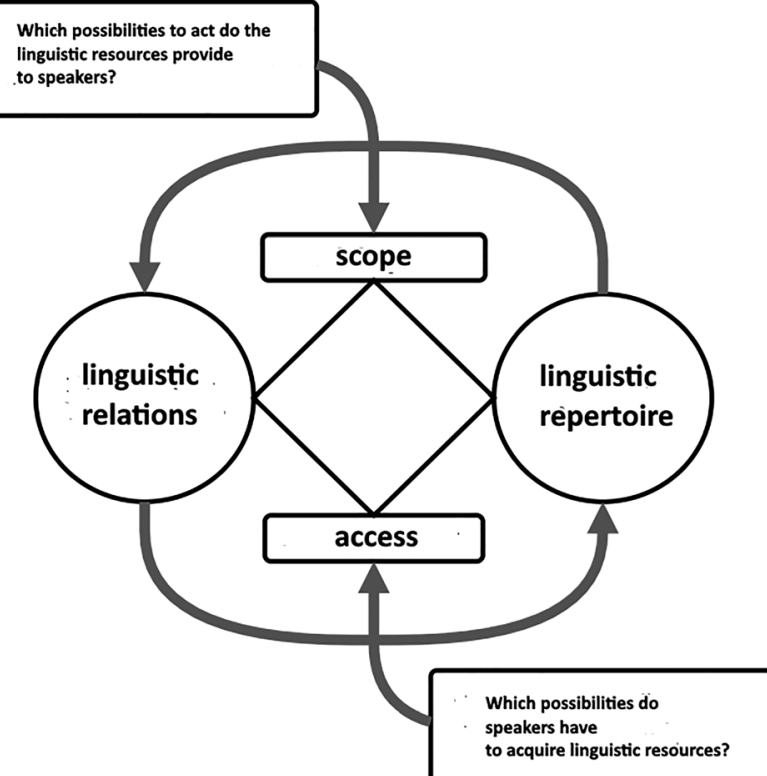

Figure 1: Theoretical framework of linguistic inequality, i.e. access, scope (Weirich 2018: 59).

official language) are not equally accessible to everyone. Access, from the perspective of a usage-based theory (Bybee 2006), which is the basis of the repertoire approach, depends on use: opportunities to listen to, speak, read and write the language in question (Romaine 2000; Zeiter 2019). Bell hooks convincingly illustrates that this applies to processes of learning language in the narrow sense of acquiring new constructions (form-meaning pairs) as well as for voice:

To make my voice I had to speak, to hear myself talk - and talk I did - darting in and out of grown folk's conversations and dialogues, answering questions that were not directed at me, endlessly asking questions, making speeches. (hooks 1999b: 337)

Having a variety of the official language as a first language does not guarantee voice, although it certainly helps. Speakers, who speak a dominant language as their first language, are not per se privileged, as they are a non-homogenous group. ${ }^{4}$ For example, in the Republic of Moldova, linguistic repertoires can differ considerably, even among Moldovans, who speak Romanian as their first

4 Contrary to what Philippe van Parijs (2011) stipulates in his approach to linguistic justice, which considers speakers of a dominant language as privileged per se. 
language. Sociolinguists attest to this for other contexts as well (see Blanchet 2016: 50; Blommaert 2008: 429; Hymes 1996 [1983]: 70). Language ideologies insisting on linguistic correctness and monolingualism affect the perceived legitimacy of speakers of non-standard varieties and the social relations among speakers. A high scope of a linguistic repertoire means having voice in various social situations, drawing on diverse forms of speech, as represented by Bakhtin's often cited term "heteroglossia" (raznorečie) (Bakhtin 1981). While Bakhtin's notion of voice stresses the uniqueness of individuals, they can only articulate their positions by drawing on publicly available semiotic resources. "Heteroglossia" accounts for the social stratification of language in disagreement with monolithic visions. However, he "does not address the question of the unequal distribution of linguistic and communicative resources characteristic of all societies." (Lähteenmäki 2010: 26) Research on learning second languages has also revealed how gender and race influence access to and the effectiveness of these learning processes (Polanyi 1995; Talburt and Stewart 1999). Access to language learning and practice depend on other speakers' readiness to engage with the learner in a respectful and empowering way. For example, in racist societies, it is a question of survival for racialized speakers not to engage in unnecessary conversations with white people. Sexism, homophobia, and transphobia will prevent women, queer, and trans-persons from having as many opportunities for linguistic exchange as more privileged speakers. All of these systems of oppression influence possibilities for mobility. ${ }^{5}$

For speakers in an advantaged situation, a relatively high scope of linguistic resources corresponds to a relatively high degree of access to these resources, due to, for example, the family language(s), exposure or access to education. For minority speakers, this is generally not the case. Such changes also change the scope of speakers' repertoires - for some, it grows, such as Romanian-speaking (bilingual) intellectuals who master the standard like Viorela; for others, especially Russian speakers, it diminishes. Restructuring processes are offset (at a different pace) when speakers start to adapt to the new circumstances - and not all speakers will be successful.

5 In 2009, I moved to a town in Russia for six months, in order to work in an intercultural project as a volunteer and to learn Russian. This was possible because of my privileges as a white German ciswoman and would not have been recommendable for a black German, and/or an openly gay person. Recently several black students had been killed by fascists in the streets of the town. The black Kenyan students in medicine I got to know in the project avoided leaving their student residence because it was not safe to do so. Besides many other dangers and disadvantages, it was much more difficult to learn Russian under these circumstances. 


\section{Mobility and immobility}

For individual biographies, two significant rupture schemes in linguistic relations can be sketched. Here, they are circumscribed as scenarios of immobility and mobility. In the former, speakers remain in the same environment, but the linguistic relations in this society undergo a dramatic change; whereas in the latter, speakers confront different linguistic relations in another society. In either case, both the scope of their linguistic repertoire and the accessibility of linguistic resources change.

\subsection{Cases}

\subsubsection{Case 1, Immobility}

Linguistic relations are dynamic and permanently evolving. Disruptions (fissures) lead to fundamental changes, if, for example, linguistic policies make essential changes to the status of a language. Typically, this happens when a new official language is declared and a normalization process is put into action. Such a break took place when the Republic of Moldova gained independence and Romanian/ Moldovan was declared the only official language. It alters the pragmatic and symbolic value of linguistic resources and necessitates adaptation and learning processes, which not all speakers will manage to do equally well. Speakers' linguistic repertoires provide an unequal basis for learning the new formal registers. Typically, these changes are contested because they are part of a shift in power relations and a reconfiguration of social relations.

\subsubsection{Case 2, Mobility}

Speakers change their everyday environment and confront new linguistic relations. This typically happens in the case of migration, when the rupture occurs in the speakers' biography. They have to adapt to a different linguistic environment in which they strive for voice. We typically think of learning a new language (e.g. Italian in the case of Viorela). Still, it can be the confrontation with other varieties and, more importantly, different ideologies and evaluations (see e.g. Boudreau 2016). Typically, these linguistic relations are initially not contested because they are perceived as legitimate and given: "every social context is normative, and most context are normative because the norms are seen as 'normal'" (Blommaert 2008: 428) (Figure 2). 


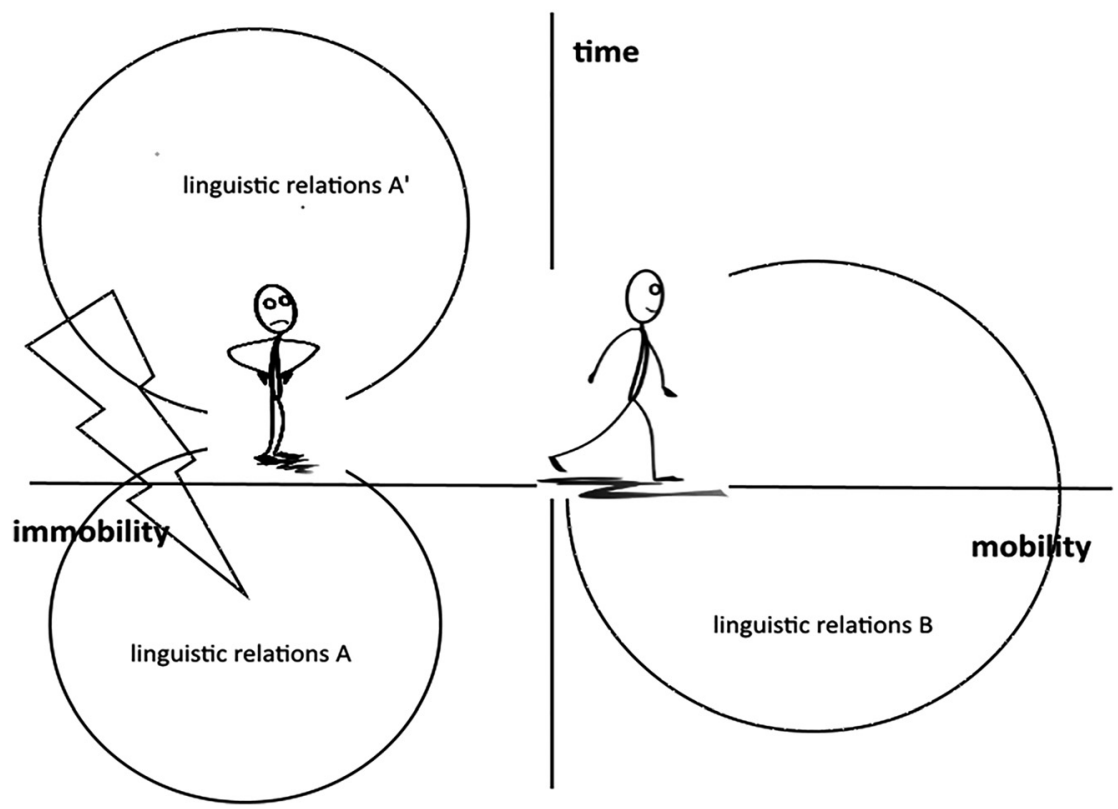

Figure 2: Change(s) of linguistic relations and (im)mobility (the stick people in this graphic were published for download under the Creative Commons $\mathrm{CCO}$. They were downloaded for use in this graphic from https://svgsilh.com/image/151823.html ("running stickman figure matchstick") and https://svgsilh.com/image/151791.html ("stickman figure matchstick angry")).

Changes in linguistic relations due to mobility and immobility are neither mutually exclusive nor unidirectional. In individual biographies and the history of communities, the experience of breaks in linguistic relations (A) as a consequence of language policy can add up with mobility experiences, as it is the case of Viorela. She lived through the radical changes brought to the linguistic relations (A) in Moldova by the 1989 language laws and was confronted with an entirely new linguistic environment (LR B) about 10 years later when she went to Italy (and again, when she came back to Moldova 12 years later, LR A'). Many mobile Moldovans look for work abroad in several different countries and regions (LR B, C, D...) and learn the necessary linguistic means.

Some (rather immobile) speakers go through several breaks in linguistic relations $\left(A, A^{\prime}, A^{\prime \prime} \ldots\right)$ in the same place. The oldest generation in village $U$. was born when this part of Moldova belonged to (Greater) Romania (between 1918 and 1940), and schooling took place in Romanian. Subsequently, they faced the foundation of the Moldovan SSR as a consequence of the Ribbentrop-Molotov pact, the reconquests by Romanian and then again Soviet troops, all going hand in hand with 
changes in language politics. Many of them were subject to forced mobility (deportations) by fascist Romanian troops allied to Germany, or Stalinist deportations to work camps, and sometimes both.

The great extent of mobility and return migration to Moldova influences the dynamics of linguistic relations in Moldova. Labor migration to Russia is one crucial reason for the widespread knowledge of Russian and Italian, which has become an integral component of linguistic relations $\left(\mathrm{A}^{\prime}\right)$ in Moldova (Weirich 2021a).

\subsection{Two examples of mobility and immobility from the Republic of Moldova}

Linguistic resources are abundant in the Republic of Moldova, a highly multilingual society. Between 1944 and 1991, Moldova belonged to the Soviet Union. There was no official state language in this period, but Russian and Moldovan, as the titular language was called during this period, were de facto co-official (Tontsch 2004). However, Russian was the more prestigious language, dominating the political and economic spheres and higher education. Since it was indispensable for social mobility, "ethnic" Moldovans tended to be bilingual in Romanian/ Moldovan ${ }^{6}$ and Russian, whereas Russian speakers often remained monolingual. As titular language, Moldovan had considerable institutional support in education and culture, but minority languages like Bulgarian, Gagauz, and Ukrainian did not.

Through three interdependent language laws, official monolingualism in Romanian/Moldovan was installed in 1989 and supported by strong ideologies of monolingualism and purism (Weirich 2015). Russian has an official status as the "language of interethnic communication", and it remains a language of education (but with diminishing scope). Independence also allowed policies for linguistic minorities to be established, who now have the right to education in their language. However, at the school level, the teaching of minoritized languages is confined to a few hours per week and the language of instruction in all minority language schools is Russian. This is both the result of and the reason that minority

6 The name of the language is controversial and remains highly politicized. According to the 1994 constitution, the name of the language is Moldovan. In 2013, the Moldovan constitutional court implicitly decided that the state language of Moldova be called Romanian even if the constitution uses a different glottonym. The controversy of the name of the language stems from its being associated with different nationalities and geopolitical orientations (Dyer 2019; Weirich 2015). 
speakers tend to use Russian in formal situations and in conversations with persons who have another L1.

The socio-economic situation in the Republic of Moldova causes labor migration on a vast scale. It is difficult to find reliable numbers because this form of mobility is often not officially reported. ${ }^{7}$ According to some prognoses, in 2035, the Republic of Moldova will have lost 45\% of its population compared to 1989 (Judah 2020). The most frequent destination remains Russia (specifically Moscow and St. Petersburg); (northern) Italy is in second place with an estimated 240,000 Moldovans (Moşneaga 2017; Weirich 2021a). Although men and women leave Moldova in a similar proportion, migration is gendered. The gender proportion varies according to place and, even more, to the type of labor Moldovans are employed in. Since interaction at work is an important occasion for language learning, gendered patterns of labor mobility indirectly influence access to linguistic resources alongside the factors mentioned in Section 2.2.

\subsection{Immobility: Ukrainian as a minority language in Moldova}

The 1989 Language Laws aimed to establish a single state language while simultaneously providing for the special status of Russian and rights for other minority languages. Conflicts arose between the politics of "normalization" of Romanian/ Moldovan and the rights of minoritized languages. In particular, the official status of Russian is controversial. It faces a moderate rollback, which considerably affects people who speak Russian as their first language and other linguistic minorities. The conflicting role of Russian, and its centrality to the linguistic repertoires of all allophones in Moldova (such as speakers of Ukrainian), are central to discussing problems of participation and voice in Moldova.

According to the 2014 census, approximately 20\% of the Moldovan population belongs to a "national minority". Ukrainians are the largest group, with about $6.5 \%$. However, not everyone who claims Ukrainian ethnicity also speaks Ukrainian as a first language. Many Ukrainians have adopted Russian as family language and language of everyday communication. The village $\mathrm{U}^{8}$ has about 2,500 inhabitants, almost all of whom have a Ukrainian dialect as their first language. Between 2010 and 2013, ethnographic fieldwork on the linguistic biographies of teachers was conducted in the village high school (liceul, 12 school years). In these

7 According to Tim Judah (2020), there was "no credible population figure" for the Republic of Moldova prior to July 2019. The British journalist also points to the problem "to determine where Moldovans abroad are. As there is no definition of what constitutes someone who should count as a member of the diaspora, its numbers range from 800,000 to two million.”

8 Name anonymized. 
interviews, the teachers narrated how they tried to adapt to the changing linguistic relations, first and foremost, on the labor market, and more specifically, as teachers. Due to their profession, preparing pupils for a career in Moldova was another major topic in all interviews.

The language of instruction is Russian. Four hours per week are dedicated to Romanian and $3 \mathrm{~h}$ to Ukrainian, as well as two or $3 \mathrm{~h}$ to an additional foreign language (English or French). Most inhabitants of the village work in agriculture. Apart from that, the school is an important employer for people with academic degrees. However, teachers' wages are too low to provide a living. ${ }^{9}$ Many inhabitants go abroad to work, either temporarily or permanently. The vice rector of the school ${ }^{10}$ explained the sociolinguistic situation of the village U. and its school as follows:

In our village, Ukrainians live compactly. When it comes to nationality, we are basically a Ukrainian village. Although nearby we have a big and rich Moldovan village, and right next to it another Moldovan village and in the other direction three small Ukrainian villages that have totally different dialects. [...] our children learn the Moldovan language as a foreign language.

At first sight, the daily linguistic practice in U. seems typical of any minority in Moldova. Most people use Russian as their formal register and in communication with non-Ukrainian-speaking persons. Still, the use of the Ukrainian vernacular in a semi-official register, for example, at the town hall or in the post office, has become more frequent since the Soviet period, when Russian was used in all formal situations. It has gained relevance for having a voice in the village. People who move to the village or commute here for work immediately get this feeling: they tend to learn it relatively fast to participate in the village's everyday communication. In local contexts, vernacular resources can be indispensable for having voice. Speakers who interact on different scales with different articulations of linguistic relations need to acquire resources appropriate to these different contexts to have voice on all of these scales (Hymes 1996 [1983]: 66).

This sociolinguistic situation can be described as double minoration (Weirich 2021b). Like Blanchet (2016: 47-48), this paper distinguishes "minoration" as a qualitative process from "minorization" as a quantitative process. Ukrainian is minor(iz)ed in relation to Romanian and Russian as the language of education in relation to the state language Romanian. As a result, speakers of Ukrainian have to deal with two different kinds of diglossia at the local and the regional or state

9 In 2015 a full monthly wage for a teacher in Moldova was 3,800 Lei (about 170 euros at that time), which is equivalent to $83 \%$ of the average Moldovan salary.

10 Interview conducted by the author on 9 April 2012, village U. (school), 50:48 min. 
Table 1: General access and scope of linguistic resources for immobile inhabitants of the village U.

\begin{tabular}{llllll}
\hline & Romanian/Moldovan & Russian & Ukrainian & English & French \\
\hline Scope & High & Medium & Low & High & Low \\
Access & Low & Medium & High & Medium & High \\
\hline
\end{tabular}

levels. Those inhabitants who engage in circular migration additionally face a temporary change in linguistic relations due to mobility (as discussed in the second example below).

This situation presents a dilemma for the teachers charged with preparing children for an independent life and ample participation in Moldovan society: The elaboration of formal registers and literacy in an idiom that is not the pupils' first language. Additionally, formal registers of Russian do not fulfill all social functions in Moldova, and for most professions knowledge of Russian and Romanian/ Moldovan is expected (Tofan 2016). Additionally, Moldovan pupils face the need to have a solid command of English, just like other young Europeans (Table 1).

The teachers describe Ukrainian as relatively accessible in U. In contrast, its scope is limited to functions in the village and media consumption. Scope and necessity of Romanian are estimated as high, but due to lack of use in the village, access is difficult. Attending Romanian-speaking institutions of higher education is an obstacle for school graduates, but many programs of higher education are offered only in Romanian. A change in the sociolinguistic situation has been felt due to a reduction of the scope of Russian. Since Russian remains central to the repertoire of most people of Ukrainian ethnic origin, their repertoire loses scope: participating in various spheres of Moldovan society is a challenge and having voice outside the village becomes more difficult. Inhabitants of the village $\mathrm{U}$. face similar problems, but their positions and strategies for dealing with these changing linguistic relations are heterogeneous.

\subsection{Mobility: (circular) migration to Italy}

Mobility has been a crucial factor in the way repertoires are understood to be changing (Blommaert 2010). As linguistic repertoires are indexical biographies that show the itineraries of the speaker, the repertoire simultaneously provides access to certain scales and is crucial for social mobility.

It focuses not on language-in-place but on language-in-motion, with various spatiotemporal frames interacting with one another. Such spatiotemporal frames can be described as "scales", and the assumption is that in an age of globalization, language patterns must be understood as patterns that are organized on different, layered (i.e. vertical rather than 
horizontal) scale-levels. And while a sociolinguistics of distribution is by and large concerned with "language" - linguistically defined objects - a sociolinguistics of mobility is concerned with concrete resources. [...] Access to and control over scales is unevenly distributed, it is a matter of power and inequality, as becomes clear when we consider typical resources for access to higher (i.e. non-local and non-situationally specific) scales such as a sophisticated standard language variety or advanced multimodal and multilingual literacy skills. (Blommaert 2010: 5)

In the Italian-speaking call center in Chişinău, Viorela was a "prototypical" operator who learned Italian while working in Italy. She lived in Rome for 12 years before returning to Chişinău for private reasons and looking for a job again. Because of her age and educational background, she stands out in contrast to most of her colleagues with the same experience. She decided to look for work in Italy when she had almost reached the pension age in Moldova. With her salary as a university professor, she was not able to make a living. And the prospect of a pension of about 700 Lei (50 euros according to the exchange rate at that time) would allow even less for a complete retirement:

da e nimic [...] pentru chisinău [...] cu aşa nu nici să te hrăneşti o lună nu ca să mai plăteşti (.) toate chestiile [...] nici să mănînci nu te ajunge [...] şi de aicia merge lupta pentru existenţă

(it’s nothing for Chisinău [...] with that you cannot even feed yourself one month [...] that's why it is a struggle for survival.)

Viorela had been a university professor in gymnastics for 26 years, a profession requiring elaborated registers in Romanian and Russian because she was teaching in both languages. She had also worked and studied in Romania and Russia, and her activities as a referee in gymnastics required knowledge of French. She had invested almost a lifetime in shaping and enhancing her voice in everyday life in Chişinău and the professional context of academia. Within the changing linguistic relations in Moldova, she had all the necessary resources for participation and having voice (see Table 2). Moving to Italy at the age of around 50 to work, she left the context of academic Chişinău and gave up her linguistic privileges (see Table 3).

Table 2: Access and scope of linguistic resources for Viorela in Chisinau (working as university professor) before migration.

\begin{tabular}{llllll}
\hline & Romanian/Moldovan & Russian & English & French & Italian \\
\hline Repertoire & Elaborated & Elaborated & - & Specified register & Basic constructions \\
Scope & High & Medium & High & Medium & Low \\
Access & High & High & Low & Medium & Low \\
\hline
\end{tabular}


Table 3: Access and scope of linguistic resources for Viorela in Italy.

\begin{tabular}{|c|c|c|c|c|c|}
\hline & $\begin{array}{l}\text { Romanian/ } \\
\text { Moldovan }\end{array}$ & Russian & English & French & Italian \\
\hline Repertoire & Elaborated & Elaborated & $\begin{array}{l}\text { Basic } \\
\text { notions }\end{array}$ & $\begin{array}{l}\text { Specified } \\
\text { register }\end{array}$ & $\begin{array}{l}\text { Basic constructions upon } \\
\text { arrival, good knowledge after } \\
\text { a few years }\end{array}$ \\
\hline Scope & Low & Low & High & Low & High \\
\hline Access & Medium & Medium & Low & Low & High \\
\hline
\end{tabular}

Her linguistic repertoire did not have the same scope in Italy as it did in Chişinău. Once she arrived in Rome, she began learning Italian to make herself understood in everyday life. She had tried to learn a few basics from her cousin (who taught Spanish at the university):

(4) nu nu am ştiut am m m venit la o verişoară de-a mea [...] predă limba spaniolă la universitate (-) şi ştie şi italiana (.) şi m-am ocupat puţin cu ea [...] oricum m-am pregătit puţin ştiam ce înseamnă cînd nu ştii limba cînd te duci într-o ţară străină (.) şi cînd n-o știi deloc

(I did not know Italian. A cousin of mine taught Spanish at the university and also knows Italian. I learned a little bit from her. Anyhow, I prepared myself a little bit. I knew what it means if you don't know the language at all when you go to a foreign country.)

Initially doing care work in Italian households, she was detached from the professional and scientific discourses of her expertise as well as from the forms of cultural discourses and consumption to which she was accustomed. Learning an L2 (and even maintaining an L1), acquiring a voice in a new environment was tough under these conditions. She had very few possibilities of use and lacked access to communication in Italian. Viorela confronts and becomes part of linguistic relations very different from those she had adapted her linguistic resources to for the first 50 years of her life. Her linguistic repertoire has less scope within these linguistic relations, and she has limited access to the linguistic resources she now needs. However, she considers herself lucky because of the first job she found, which allowed her to quickly learn some basics.

(5) Şi după aceea am lucrat cînd am ajuns în roma a cincea zi m-am aranjat la lucru şi am făcut baby sitter cu un baieţel de opt ani (.) [...] nuştiu a fost un noroc sau cum / a fost baieţelul foarte dezgheţat (.) aşa [...] î cam ca mine (.) 
am început să ne jucăm una alta şi prin jocuri una alta [...] poate vreo lună cum eram pregătită cîteva cuvinte fraze le ştiam şi am început cu dînşii să învăţăm limba română chiar la calculator (-) cu baiatul şi [...] şi stateam cu dînsul cît foarte mult mai petreaceam timp (.) şi pîn 7 luni şi jumate am stat cu dînsul (.) şi aşa m-am de acuma de cînd am plecat de la dînşii mă simţeam bine (.) [...] cu limba [...] eram: cum adică sigură de mine (when I arrived in Rome, on my fifth day I found work and I was the babysitter of an eight-year-old. I was lucky because the boy was very openminded, like I am. We started playing and during these games one came to another. And after a month or so when I was ready, when I knew a few words and phrases, we started to learn at the computer. [...] we spent a lot of time together, and I stayed seven and half months with him, and when I left them I felt sure about the language, I was self-confident.)

Many mobile people who work as badante learn Italian by interacting with small children and from television and magazines. Researchers working with the linguistic biographies of mobile women have documented similar experiences (see the example of Mrs. L in Busch [2016]).

Participating in the new linguistic relations in addition to the political discourse drives the desire to learn the official language. Migrant learners happen to perceive it as "indispensable and highly desirable but at the same time almost unattainable", according to Busch (2016: 9). "Desirable but almost unattainable" reflects the dimensions of scope and access - knowledge of the official language is desirable because it has scope, it is indispensable for having voice, but access is difficult. This is the typical situation of minored speakers towards the official or dominant language, and in some respects comparable to the relation of Ukrainians in Moldova towards the state language (in Example [1]). Compared to other immigrants, Viorela was in an excellent position to learn Italian because of her linguistic repertoire and her academic training:

(6) da a fost procesul ă:m eu singură am studiat am luat tot ce-mi trebuia în manuale dicţionare (.) absolut tot am avut cu mine (.) î̀ aşa asta prima metodă

(I learned by myself. I took everything I needed with me: manuals, dictionaries. I had everything with me. That was the first method.)

(7) e clar am început să citesc mergeam la film (.) î la televizor muzică şi tot aşa şi după asta cîte oleacă eram nu zic excelent [...] dar oricum dacă-şi dai interesul cu atît mai mult că se aseamănă foarte mult cuvinte <<in Italian> semile> nu [...] foarte multe şî numai cît şi puţin gramatica 
(of course I started to read, I went to the movies, television, music and so forth. After a while I was, I am not saying excellent but anyway [...] if you are interested, even the more so since there are many <<in Italian> similarities> [between Romanian and Italian])

Once she had acquired the necessary linguistic resources as well as legal status after several years in Italy, she worked in jobs that were linguistically more demanding. Although she insists that she enjoyed living in Rome, she decided to return to Chişinău because she missed family life. Here she successfully applied for a job as a telephone operator in an Italian-speaking outbound call center, where she sold prepaid contracts to mobile phone users in Italy. At the time of the interview, she had worked at the call center for seven months and was considering going back to Italy, embarking on a journey of circular migration.

Having voice can mean different things concerning Viorela's biography. In her years as a university professor, it meant being heard and listened to by students and her academic community as a teacher and researcher, and it implied having academic registers in the field of gymnastics in Russian and Romanian. It also meant having authority as a referee in gymnastics, which implied knowing French. And of course, it also meant making herself understood in many everyday situations that were not a subject of the interview. Her initial focus in going to Italy was to make herself understood in everyday situations, something that she could take for granted and did not have to worry about in Chişinău. It meant developing a basis in Italian that was sufficient to find jobs in housekeeping and babysitting. As a babysitter, Italian became more accessible because the job provided her with possibilities of use. At the same time, she had to make herself understood and listened to for fulfilling her duties as a babysitter. Her quickly evolving linguistic repertoire also provided her access to other kinds of jobs, none of which demanded the rigorous qualifications she acquired in Moldova.

When she returned to Chişinău and the linguistic relations she was accustomed to, she found a new job requiring significant learning processes to successfully communicate as a telephone operator. She participated in linguistic training, which was the first time she systematically studied aspects of Italian with a teacher in an institutional context that produced learning processes concerning metalinguistic knowledge of grammar and writing. But she also had to learn to be convincing and to make sales on the telephone, sometimes defending herself against insults from customers who did not want to receive marketing calls.

A repertoire's reach also depends on the contexts in which it can be used. Viorela never had the same opportunities to speak in Italy as she did in Moldova, because her daily activities and everyday communication differed. Even after several years of living as a Moldovan migrant in Italy, she had fewer possibilities of being 
heard than in her position as a university professor in Chişinău. But since having voice also depends on status and institutional context, even after returning to Moldova after 12 years, Viorela does not have the same voice she had before she left.

\section{Linguistic relations, repertoires and participation}

This paper has presented two different scenarios of (im)mobility and ruptures of linguistic relations. More specifically, it has examined the processes of linguistic adaptation, language learning, and the restructuring of linguistic repertoires that ruptures set in motion. We have shed light on these processes by looking at the scope of linguistic repertoires under specific conditions (linguistic relations) and the access to linguistic resources.

This last chapter discusses whether it is adequate to call the aim of these learning processes participation. We need to name what we believe sociolinguistic inequalities consist of and, consequently, what the goal of learning processes is. Usage-based approaches (Bybee 2006; Tomasello 2003) share the assumption that striving for autonomy (Castellotti and Moore 2011; Maas 2008: 272, 2010: 55; Zeiter 2019: 151) or voice (Blommaert 2010: 180f; Blommaert and Backus 2013: 29f; Busch 2016a) is the aim of individual language learning. This does not require the individual to be conscious of this or explicitly strive for autonomy as the goal of learning (and even less so at an early age, in the ontogenetic perspective). Increased autonomy via language learning (in the understanding of Utz Maas 2008: 283) starts with the premise that language learning always refers to learning the language of others. Linguistic forms shared with other members of a linguistic community enable symbolic representation, for example, of conflict and their resolution on a symbolic level (Maas 2008: 272).

I suggest reserving "autonomy" as the aim of language learning processes in a strict sense of acquiring the means to communicate in that language, especially in the ontogenetic perspective but also for L2 learning in the context of migration into different linguistic relations. Participation is closely related to the proclaimed aims of the modern nation-state (see above), but participation can also refer to other dimensions of social life. Participation is a formal and abstract criterion that does not necessarily imply meaning and content. This paper proposes using the notion of voice in the sense of being heard when it comes to the expression of interests, opinions and political claims.

In critiquing language policy and sociolinguistic relations, Utz Maas looks at equity from the perspective of participation by asking which choices language and 
education policy must make to enable the most significant portion of citizens to participate in the social and political sphere. But what does it mean, from a linguistic point of view? What are the linguistic conditions for participation? Participation (in different fields of social, economic, and political life that will have to be specified) is certainly one dimension of the scope of linguistic resources; access to these linguistic means is a condition for their scope. Communication is a social activity to which language is the most important means and central to participation (Blanchet 2016: 35). But what does participation mean concretely?

Participation is closely related to liberal democratic states that are legitimized via participation (Blanchet 2016: 35). In this sense, ideas of participation often reflect "Minority World norms" as Tisdall and Samantha (2012: 254) have underlined in respect to "notions of appropriate participation for children and young people [that are] not even universal in their own contexts." Since the national scale as a primary scale of political organization and the establishment of language policies is central to the concept of social relations, so is participation. ${ }^{11}$ According to this ideology, political claims to equal opportunities for participation are legitimate. However, participation in this sense is problematic because it can also imply complicity. Participation is a condition for transformation and resistance, but these are not the number one political aims in discourse about participation. Claims for participation are first and foremost claims to participate in the current system (that systematically and structurally excludes some people even if it claims something else) and playing by its rules. When speaking about studying in white institutions as a black woman, bell hooks (1999a: 342) cautions: “[...] I would be 'tried', made to feel as though a central requirement of my being accepted might be my participation in this system of exchange to ensure my success”.

Taking the state as a point of reference is problematic for several reasons. A major reason is the issue of the moral and political nature of the state. It also means asking whether rights and measures refer to only citizens or to non-citizens alike (Hirsch 2005: 72-73; Schneider 2010). The question of exclusion or inclusion is constitutive for democratic states (Maas 2008: 127).

If a "named" language (Otheguy et al. 2015) and, more specifically, a standard variety of this language is the vehicular language of the democratic state, a prerequisite for participation is the capacity to communicate in this language. Access to this capacity is unequally distributed. The educational system exists in order to teach children (and eventually adults) the necessary knowledge. Therefore, demands for equal access to education and language learning are legitimate in liberal democratic states - as they underscore that the state must keep its promise of participation. As such, participation becomes a moral aim for educational policy.

11 For a more ample discussion of different dimensions of participation see Weirich (2021b). 
An underlying premise is that languages and registers can be learned - which is true. But when it comes to participation and voice, speakers considered "nonnative" or speakers of non-standard varieties tend to be considered less legitimate (Blanchet 2016; Blanchet and Stéphanie 2018; Cameron 2012: 255). If this claim to participation is to be taken seriously, it has to account for the multilingual repertoires of everyone, as well as the different social conditions for learning. Thus, focusing on language policies means providing the opportunity to acquire the official language but not without recognizing the difficulties and different conditions involved in doing so. But it could also mean providing for translation and guaranteeing participation in languages other than the state language. This is neither a problem of comprehension nor of equality, but it contests the symbolic and legitimizing functions of the official language and the founding principles of nation-states' ideologies.

\section{Conclusions}

Established sociolinguistic relations are dynamic and undergo long-term processes of change. But sometimes historical events cause drastic shifts, which result in new sociolinguistic relations. In a biographical perspective, moments that change the usual course of everyday life, can be qualified as "breaks". From the individual's point of view, this can happen because of biographic events or migration but also because of political-historical cesuras. The declaration of a new state language affects the position of speakers within a society. Access to education, work, and other spheres of social life depend on their capacity to adapt to the new linguistic relations. Some individuals and groups who used to have voice under specific linguistic relations see its scope reduced when linguistic relations change.

With the help of the concepts of access and scope, we can describe which social functions specific linguistic resources have (scope) and how speakers are positioned to acquire these resources (access). These concepts illustrate speakers' relationships to their linguistic resources as currently (un)available and potentially (un)learnable, depending on the social context in which they are practiced. One perspective under which cases of rupture can be analysed, is a continuum of (im)mobility. Ruptures of linguistic relations set off processes of linguistic adaptation, language learning and restructuring linguistic repertoires. The aim of such adaptation processes has often been discussed from the angle of participation. Such perspectives should be carefully examined. While participation is a condition for transformation and resistance, they are not the top political aims in such a discourse. Claims for participation are first and foremost claims to participate in 
the current system, which risks overlooking mechanisms of exclusion inherent in democratic states.

From a linguistic point of view, we can describe the linguistic forms and means necessary to participate or have voice in different social situations while keeping in mind that these linguistic means will have other impacts depending on the speaker and the situation. Some social structures and patterns influence potentials of voice and are ultimately context-specific. A context-sensitive analysis must be intersectional because what counts as a voice mostly has to do with judgments about gender, race, and social class. This paper argues that the notions of scope and access can be useful for such research. This implies a thorough description of the linguistic relations and their articulation in these cases: Which linguistic forms have scope? How accessible are they? Although the realization of voice is contextspecific, languages of power and especially the Geschäftssprache, a state's official language and the dominant language in sociolinguistic relations, is a prerequisite for having voice. In this sense the linguistic repertoires of individuals reflect the power relations under the sociolinguistic relations they have experienced throughout their linguistic biographies. But more than knowledge of the language of power, a powerful voice can appropriate and transform language and not just to reproduce powerful ways of speaking (hooks 1999a: 342).

Access to linguistic resources in itself is shaped by intersectional forms of inequality: access to education and other spheres of social life such as culture or politics is unequal, but also anxieties and linguistic insecurity that come in the way of developing voice:

Now when I ponder the silences, the voices that are not heard, the voices of those wounded and/or oppressed individuals who do not speak or write, I contemplate the acts of persecution, torture - the terrorism that breaks spirits, that makes creativity impossible. (hooks 1999b: 339)

\section{Transcripton conventions}

(.) short pause

[...] omission

/ Anakoluth

Acknowledgements: This work could be realized thanks to a fellowship from the Volkswagen Stiftung. An early version of this paper was presented at the workshop "On the notion of 'Having a Voice' in Social Research. Between Moral Imperative and Scientific Analysis”, held online May 28 and 29, 2020. https:// voiceinsocialresearch.wordpress.com/ 


\section{References}

Bakhtin, Mikhail Mikhailovich. 1981. Discourse in the Novel (1934-35). In Michael Holquist (ed.), The dialogic imagination. Four essays by M. M. Bakhtin, 259-422. Austin: University of Texas Press.

Blanchet, Philippe. 2016. Discriminations. Combattre la glottophobie. Paris: Textuel.

Blanchet, Philippe \& Clerc Conan Stéphanie (eds.). 2018. Je n'ai pas osé ouvrir la bouche. Témoignages de glottophobie vécue et moyens de se défendre. Limoges: Lambert-Lucas.

Blommaert, Jan. 2008. Grassroots literacy. Writing, identity, and voice in central Africa. London: Routledge.

Blommaert, Jan. 2010. The sociolinguistics of globalization. Cambridge, UK \& New York: Cambridge University Press.

Blommaert, Jan \& Ad Backus. 2011. Repertoires revisited: 'Knowing language' in superdiversity (Working Papers in Urban Language \& Literacies, 67). https://www.academia.edu/6365319/ WP67_Blommaert_and_Backus_2011._Repertoires_revisited_Knowing_language_in_ superdiversity (accessed 12 June 2020).

Blommaert, Jan \& Ad Backus. 2013. Superdiverse Repertoires and the individual. In Ingrid de Saint-Georges \& Jean Jacques Weber (eds.), Multilingualism and multimodality. Current challenges for educational studies, 11-32. Rotterdam: Sense Publishers.

Bochmann, Klaus. 1997. Der Name der Sprache und die wissenschaftliche Wahrheit. Ein sprachpolitischer Erlebnisbericht aus der Republik Moldova. Quo Vadis, Romania 10. 77-85.

Bochmann, Klaus. 2007. Sprache und Identität in mehrsprachigen Regionen in Osteuropa Theoretische und methodische Ausgangspositionen. In Klaus Bochmann \& Vasile Dumbrava (eds.), Sprachliche Individuation in mehrsprachigen Regionen Osteuropas. Republik Moldova, vol. 1, 13-41. Leipzig: Leipziger Universitätsverlag.

de Bot, Kees, Wander Lowie \& Markolijn Verspoor. 2007. A Dynamic Systems Theory approach to second language acquisition. Bilingualism 10(1). 7-21.

Boudreau, Annette. 2016. À l'ombre de la langue légitime. L'Acadie dans la francophonie. Paris: Classiques Garnier (Linguistique variationnelle, 2).

Busch, Brigitta. 2012. Das sprachliche Repertoire oder Niemand ist einsprachig. Vorlesung zur Verleihung der Berta-Karlik-Professur an der Universität Wien. https://heteroglossia.net/ fileadmin/user_upload/publication/Busch_Sprachliches_Repertoire.pdf (accessed 12 June 2020).

Busch, Brigitta. 2013. Mehrsprachigkeit. Stuttgart: UTB.

Busch, Brigitta. 2016. Heteroglossia of survival: To have one's voice heard, to develop a voice worth hearing (Working Papers in Urban Language \& Literacies, 188). https://www. academia.edu/20304151/WP188_Busch_2016._Heteroglossia_of_survival_To_have_ones_ voice_heard_to_develop_a_voice_worth_hearing (accessed 12 June 2020).

Bybee, Joan. 2006. From usage to grammar: The mind's response to repitition. Language in Society 82(4). 711-733.

Cameron, Deborah. 2012. Epilogue. In Ken Hyland \& Carmen Sancho Guinda (eds.), Stance and voice in written academic genres, 249-256. Basingstoke: Palgrave Macmillan.

Castellotti, Véronique \& Danièle Moore. 2011. Compétence plurilingue et pluricultruelle. Genèses et évolutions. In Philippe Blanchet \& Patrick Chardenet (eds.), Guide pour la recherche en didactique des langues et des cultures. Approches contextualisées, 241-252. Paris, Montréal: Éditions des archives contemporaines; Agence universitaire de la francophonie. 
Duchêne, Alexandre \& Monica Heller (eds.). 2008. Discourses of Endangerment. Ideology and Interest in the Defense of languages. London: Bloomsbury.

Dyer, Donald. 2019. “I don't care if it is true, I don't believe it!”: The Linguistic Shibbeloth of Moldovan. In Papers for Christina E. Kramer on the Occasion of Her Retirement (Balkanistica 31:2), 19-44.

Erfurt, Jürgen. 1994. Glottopolitisch initiierter Sprachwandel. Brockmeyer (Sprachdynamik. Auf dem Weg zu einer Typologie sprachlichen Wandels 5). Bochum: Brockmeyer.

Erfurt, Jürgen. 2002. Dimensiunile Sociolingvistice ale limbii române vorbite. In Klaus Bochmann \& Vasile Dumbrava (eds.), Limba Româna vorbita în Moldova istorica, vol. 1, 15-36. Leipzig: Leipziger Universitätsverlag.

Erfurt, Jürgen. 2003. Plurizentrischer Sprachausbau und die Herausbildung von Standardvarietäten in Moldova und Québec. Quo Vadis, Romania 22. 8-21.

Heller, Monica. 2008. Languages and the nation-state. Challenges to sociolinguistic theory and practice. Journal of Sociolinguistics 12(1). 504-524.

Heller, Monica. 2016. Undoing the maco/micro dichotomy: Ideology and categorisation in a linguistic minority school. In Nikolas Coupland, Srikant Sarangi \& Christopher Candlin (eds.), Sociolinguistics and social theory, 212-234. London, New York: Routledge (Language in social life series).

Heller, Monica \& Alexandre Duchêne. 2012. Pride and profit: Changing discourses of language, capital and nation-state. In Alexandre Duchêne \& Monica Heller (eds.), Language in late capitalism. Pride and profit, 1-21. New York: Routledge.

Hirsch, Joachim. 2005. Materialistische Staatstheorie. Transformationsprozesse des kapitalistischen Staatensystems. Hamburg: VSA.

Holborow, Marnie. 2015. Language and Neoliberalism. Abingdon, New York: Routledge.

hooks, bell. 1999a. Marginality as site of resistance. In Russell Ferguson \& Marcia Tucker (eds.), Out there. Marginalization and contemporary cultures, 341-343. Cambridge, Mass: The MIT [Massachusetts Institute of Technology] Press.

hooks, bell. 1999b. Talking back. In Russell Ferguson \& Marcia Tucker (eds.), Out there. Marginalization and contemporary cultures, 337-340. Cambridge, Mass: The MIT [Massachusetts Institute of Technology] Press.

Hymes, Dell. 1996 [1983]. Report from an underdeveloped country: Toward linguistic competence in the United States. In Dell Hymes (ed.), Ethnography, linguistics, narrative inequality, 63-105. London: Taylor \& Francis.

Judah, Tim. 2020. Moldova faces 'existential’ population crisis. https://balkaninsight.com/2020/ 01/16/moldova-faces-existential-population-crisis/?fbclid=IwAROpZ4LEJv_ pVQcb8N9kmkRd19RelhKpLL07d2Djy6K0e08MqP5QeK8z5xo (accessed 12 June 2020).

Lähteenmäki, Mika. 2010. Heteroglossia and voice: Conceptualising linguistic diversity from a Bakhtinian perspectice. In Mika Lähteenmäki \& Marjatta Vanhala-Aniszewski (eds.), Language ideologies in transition. Multilingualism in Russia and Finland, 17-33. Frankfurt am Main: Peter Lang.

Lüdi, Georges \& Bernard Py. 2009. To be or not to be... a plurilingual speaker. International Journal of Multilingualism. 6. 154-167.

Lüdi, Georges. 2014. Le "parler plurilingue” comme lieu d'émergence de variétés de contact. In Robert Nicolaï (ed.), Questioning language contact. Limits of contact, contact at its limits, 58-90. Leiden \& Boston: Brill. 
Maas, Utz. 1985. Lesen - Schreiben - Schrift. Die Demotisierung eines professionellen Arkanums im Spätmittelalter und in der frühen Neuzeit. Lili. Zeitschrift für Literaturwissenschaft und Linguistik 59. 55-81.

Maas, Utz. 1989. Sprachpolitik. Grundbegriffe der politischen Sprachwissenschaft. In Utz Maas (ed.), Sprachpolitik und politische Sprachwissenschaft. Sieben Studien, 16-63. Frankfurt am Main: Suhrkamp.

Maas, Utz. 2005. Sprache und Sprachen in der Migration im Einwanderungsland Deutschland. IMIS-Beiträge 26. 89-133.

Maas, Utz. 2008. Sprache und Sprachen in der Migrationsgesellschaft. Göttingen: V\&R Unipress. Maas, Utz. 2010. Literat und orat. Grundbegriffe der Analyse geschriebener und gesprochener Sprache. Grazer Linguistische Studien 73. 21-150.

Moșneaga, Valeriu. 2017. Mapping Moldovan diaspora in Germany, UK, Israel, Italy, Portugal and Russia. Chisinau: International Organization for Migration, Mission to Moldova.

Otheguy, Ricardo, Ofelia García \& Wallis Reid. 2015. Clarifying translanguaging and deconstructing named languages: A perspective from linguistics. Applied Linguistics Review 6(3). 281-307.

Polanyi, Livia. 1995. Language learning and living abroad: Stories from the field. In Barbara F. Freed (ed.), Second language acquisition in a study abroad context, 271-292. Amsterdam, Philadelphia: John Benjamins.

van Parijs, Philippe. 2011. Linguistic justice for Europe and for the world. Oxford: Oxford University Press.

Romaine, Suzanne. 2000. Language in society. An introduction to sociolinguistics, 2nd ed. Oxford, New York: Oxford University Press.

Schneider, Britta. 2010. Deconstructing national identity - What does it mean for Language Rights. In Markus Bieswanger, Heiko Motschenbacher \& Susanne Muehleisen (eds.), Language in its socio-cultural context. New explorations in gendered, global and media uses, 173-197. Frankfurt am Main: Peter Lang.

Talburt, Susan \& Melissa A. Stewart. 1999. What's the subject of Study abroad?: Race, gender, and “Living culture”. The Modern Language Journal 83(2). 163-175.

Tisdall, E. Kay M. \& Punch Samantha. 2012. Not so ‘new’? Looking critically at childhood studies. Children's Geographies 10(3). 249-264.

Tofan, Alina. 2016. Mehrsprachigkeit in der Republik Moldau aus autobiografischer Perspektive, vol. 7. Leipzig: Leipziger Universitätsverlag.

Tomasello, Michael. 2003. Constructing a language. A usage-based theory of language acquisition. Cambridge, Mass: Harvard University Press.

Tontsch, Günther. 2004. Minderheitenschutz im östlichen Europa. Moldau. https://iorr.uni-koeln. de/sites/ostrecht/forschung/Minderheitenschutz_im_oestlichen_Europa/Moldau_ Tontsch.pdf (accessed 12 June 2020).

Vietti, Francesco (ed.). 2012. Il paese delle badanti. Una migrazione silenziosa. Torino: Società editrice internazionale.

Weirich, Anna-Christine. 2015. Einige Gedanken zu aktuellen Entwicklungen des Glottonymstreits in der Republik Moldova. Quo Vadis, Romania 46. 106-129.

Weirich, Anna-Christine. 2018. Sprachliche Verhältnisse und Restrukturierung sprachlicher Repertoires in der Republik Moldova. Berlin: Peter Lang.

Weirich, Anna-Christine. 2021a. Italian as minority language, foreign language and language of migration in the Republic of Moldova. In Annemarie Sorescu-Marinković, Mihai Dragnea, 
Thede Kahl, Blagovest Njagulov, Donald L. Dyer \& Angelo Costanzo (eds.), Language and the politics of identity. The Romance-speaking Balkans, 76-114. Leiden: Brill.

Weirich, Anna-Christine. 2021b. 'Scope' of linguistic resources and the social participation of the Ukrainian population in the Republic of Moldova. In Jean-Rémi Carbonneau, Fabian Jacobs \& Ines Keller (eds.), Dimensions of cultural security for national and linguistic minorities, 477-509. Brussels: Peter Lang (Diversitas).

Zeiter, Anne-Christel. 2019. Silence, on s'occupe de vous! Barrières à la socialisation langagière dans l'accueil des requérants d'asile en Suisse. Minorités linguistiques et société/Linguistic Minorities and Society 12. 148-166. 